\title{
Emerging strategic corporate social responsibility partnership initiatives in agribusiness: the case of the sustainable agriculture initiative
}

\author{
Katharina Poetz ${ }^{1}$, Rainer Haas ${ }^{2}$ and Michaela Balzarova ${ }^{3}$ \\ ${ }^{1}$ Institute of Food and Resource Economics, Copenhagen University, Rolighedsvej 25, 1958 Frederiksberg C, Denmark; kpo@foi.ku.dk \\ ${ }^{2}$ Institute of Marketing \& Innovation, University of Natural Resources and Life Sciences Vienna (BOKU), Feistmantelstrasse 4, 1180 \\ Vienna, Austria \\ ${ }^{3}$ Faculty of Commerce, Lincoln University, Te Whare Wanaka o Aoraki, P.O. Box 84, Lincoln 7647, Christchurch, New Zealand
}

\begin{abstract}
Over the past 20 years the concept of Corporate Social Responsibility (CSR) has gained momentum in business practices and strategies. In the agribusiness sector, the need for CSR integration has recently triggered a number of private sector led initiatives that should contribute to sustainable agricultural practices. Consequently we emphasize that for managing innovation processes for sustainability and their institutional context, the food sustainability discourse also needs to investigate the state of the art of CSR in agribusiness. Based on a model to compare and contrast accountability standards we analyse the Sustainable Agriculture Initiative (SAI) platform and its principles. We conclude that over the past 5 years agribusiness corporations have become more pro-active in addressing sustainability concerns, and mainstream initiatives start to compete with the traditional niche markets. The SAI was founded by three big players in the food industry, and represents a global initiative among a number of private-sector driven institutional innovations for the sustainability transformation of the mainstream parts of the sector. In order to evaluate and exploit their potential for sustainable development, we advise scholars, policy makers, and managers to not only address questions about legitimacy and stakeholder involvement, but also take strategic objectives into account.
\end{abstract}

\section{Sustainable development and corporate social responsibility}

Corporate Social Responsibility (CSR) has become part of a cluster of overlapping terms that includes sustainable development, sustainable business, socially responsible business, green management, corporate citizenship and ethical business (Zorn and Collins, 2007). The concept usually refers to the triple bottom line (Elkington, 1998), and encompasses the 'economic, legal, ethical, and philanthropic expectations placed on organisations by society at a given point in time' (Carroll and Buchholtz, 2002). This definition can be found among a wide range of others, making CSR at most an umbrella term under which a seemingly unlimited number of social and ecological activities of companies exist (Senge, 2006). For the companies themselves the lack of one universally accepted definition of CSR is considered less problematic than the lack of guidance on how to manage challenges that arise from the phenomenon:

"Therefore, the challenge for business is not so much to define CSR, as it is to understand how CSR is socially constructed in a specific context and how to take this into account when business strategies are developed' (Dahlsrud, 2006).
From a strategic perspective, the business case of CSR, i.e. the notion that CSR investment can provide returns to the company (e.g. through decreased production inefficiencies, cost and risk reductions, and increased sales), is seen as the main driver for CSR activities (Cruz and Wakolbinger, 2008). A growing number of surveys suggesting that consumers do care about the ethical performance of companies and are increasingly interested in CSR (Fliess et al., 2007) made further room for the business case of CSR. Based on stakeholder theory (Freeman, 1984; Phillips and Freeman, 2003), the hypothesis for corporate responsibility is that CSR provides individual stakeholders with benefits, and a company that engages in substantial levels of CSR can expect rewards from their stakeholders (Bhattacharya et al., 2009). What is considered substantial has been shaped by globalization processes and the development of the concept over time. The recent 'third generation' of CSR (Stohl et al., 2007) is characterized by a shift towards integration and collaboration (Dunphy et al., 2003), and a system-based approach (Bullis and Ie, 2007). Today's corporations are now expected to apprehend their social responsibility not only for internal affairs, but also along the entire supply chain (Bowie and Werhane, 2005). In practice, CSR is also driven by political and socio-economic developments. Although voluntariness is one of the defining elements of CSR (Dahlsrud, 2006), increased stakeholder pressure from 
political agendas has led to a quasi-mandatory side of CSR (Konrad et al., 2008). CSR is addressed by corporations and managers, but governments define the scope of CSR, and shape it with a soft-law approach that includes information tools, agreements, partnerships, and other voluntary softpolicy instruments (Steurer and Berger, 2007). Socioeconomic drivers for CSR include the recent economic and financial crisis and numerous corporate scandals (Aßländer and Senge, 2009), as well as an increasing number of socially conscious and well informed consumers and watchdog groups that voluntary monitor and reveal 'greenwashers' (Ongkrutraksa, 2007).

For corporations, the third generation of CSR is a challenge to business strategy. New stakeholders and different national legislations change expectations and alter how social, environmental, and economic impacts should be optimally balanced in decision making (Dahlsrud, 2006). As a result CSR becomes increasingly integrated and blurred with issues of corporate strategy, management and governance, including for example corporate lobbying, business taxes paid to governments, and product stewardship (White, 2005).

\section{Corporate social responsibility and agribusiness}

CSR applies to all sectors; however, CSR has a different initial position in food and agriculture. Due to food security and health issues, there has always been an urge for governmental control of safety aspects of the food system. The bovine spongiform encephalopathy crisis in the 1990s and associated revisions of European food law are, together with globalization, driving forces for debates on the division of coercive and voluntary aspects of food safety regulation (Sikor, 2008). International and national governments respond to the challenge of internationalized food markets and decreased safety perceptions of consumers by imposing new legislation and regulations that should ensure safe and animal-friendly production, restrict pollution and save resources (Trienekens and Zuurbier, 2008). Beyond food safety, concerns about the intensification in agriculture and irresponsible treatment of soils date back to the emergence of organic farming in the beginning of the 20th century. On the social side, Fair Trade and Ethical Trade products have entered the market as a response to growing awareness for social and development issues (Young, 2003).

Next to growth in organic and fair trade, which are still niche markets (Haas et al., 2010), there is also increased pressure on mainstream agriculture and food production to become more socially and environmentally responsible. Consumers are concerned about health issues and demand safe food and tangible quality characteristics; however, this demand has been supplemented by a request for ecological, ethical and socio-economic quality aspects for the whole product range (Boller et al. 2004). Boehlje (1993) already noted that the CSR in agribusiness means that food companies have a societal duty and supply chain responsibility beyond public relations gestures, and Aiking and De Boer (2004) emphasize transparency and good governance as key for their operations. In practice, activist networks such as the 'Agribusiness Action Initiative' (AAI, 2011) have started to question corporate power in global food production, and raise awareness for socio-economic impacts of the current food system.

In sum, changing consumer demands, tighter food legislation and globalized markets urge food businesses to strengthen quality and safety control, establish traceability and concurrently shift from bulk production to high valueadded specialties that require collaborations with other parties (Trienekens and Zuurbier, 2008), as well as adoption of a holistic view of the entire supply chain (Studer $e$ t al., 2009). To operationalize CSR, standards, codes, platforms, and process models can contribute to sustainable supply chains and risk management (McEwan and Bek, 2009; Teuscher et al., 2006). Standards on tangible quality characteristics and food safety have historically played a major role in the sector, but are usually considered as mandatory or quasi-mandatory, and not part of CSR (Vander Stichele et al., 2006). For social responsibility, organic and fair trade standards have established themselves in niche markets. However, agribusiness is seen as about five to ten years behind the manufacturing industry in the development of industry-wide CSR standards and their implementation. Because of the diversity of the sector, and fewer CSR drivers, standards have evolved for different products, regions, and production methods (Smith and Feldman, 2004). However, the call for CSR in mainstream agribusiness operations has increased pressure for companies to engage in industrywide CSR initiatives, including standards, guidelines, and platforms.

\section{Problem statement}

Food sustainability in terms of the environmental, social and economic consequences of food production (Aiking and De Boer, 2004) is a central element of the overall sustainability debate. For managing innovation processes for sustainability and their institutional context, the food sustainability discourse also needs to investigate the state of the art of CSR initiatives in agribusiness. Given the discussion about the third dimension of CSR and strategic 
integration, it is timely to review institutional innovations in the form of agribusiness-specific private sector initiatives, notably CSR related standards, guidelines, or networking and development platforms. The questions we start to answer in this article are: What kind of private-sector led partnership initiatives for sustainable agriculture have emerged? To what extend can strategic CSR integration be seen in such initiatives? What is the aim and scope of such initiatives? And, who is involved and why? Our aim is to approach these questions through a single case study analysing the first global private sector led CSR initiative in agribusiness, the Sustainable Agriculture Initiative (SAI) platform and its principles. The SAI platform and its principles is the only global food industry initiative for sustainable agriculture (SAI, 2010b). Thus SAI represents a benchmark and interesting case for analysing CSR related institutional innovations. For case analysis we use an adapted version of Rasche's (2009) model for facilitating contrast and comparisons of accountability standards. In doing so, first we contribute toward the understanding of the start-of-the-art of operationalized CSR through institutional innovations in the form of private sector partnerships in the agro-food sector. Second, we contribute to understanding the embedded sustainability potential and limitations to mitigate negative environmental and social impacts. Furthermore, through this paper we strive to reduce information asymmetry created by producers of agricultural CSR initiatives in order to provide credible information related to content, process and context of scrutinized SAI platform and its principles.

We position our paper within studies that explore institutional changes due to strategic CSR integration, and their potential for sustainability transformation. In line with the criticism on CSR standards, we emphasize that initiatives such as the SAI are not a panacea (Vogel, 2010). Yet their potential contribution to sustainable development should not be undermined. We intend to provide an indepth understanding of institutional structures and drivers behind the only global food industry initiative for sustainable agriculture. We hope that this approach will allow us to better assess and exploit the potential for sustainable development embedded in initiatives such as the SAI. Furthermore, CSR initiatives also need to be compared to actual policy alternatives (Vogel, 2010). We also hope to lay the foundations for systematic comparisons with other initiatives for sustainable agriculture, and the kind of questions that may be addressed in such a study.

\section{Method}

Guided by the questions in the problem statement, we applied an exploratory approach starting with a search of private-sector led CSR initiatives in agriculture and agribusiness, followed by the selection of a specific case, the collection of secondary case data, and a systematic qualitative content analysis.

We started the study with our first question on what kind of private-sector led partnership initiatives for sustainable agriculture have emerged. For the search we relied on the outcomes of a larger project about CSR standards and initiatives across several industries. The project involved a search for CSR standards, guidelines and other initiatives in existing lists and surveys, and in both academic and grey literature. The search started with entering the terms 'CSR standards', 'CSR guidelines' and 'CSR instruments' in various combinations (including CSR in its written full form) into search engines of academic publishing consortiums (notably ScienceDirect, Wiley-Blackwell, SpringerLink), and into Google (Scholar). Subsequently, some lists and cases provided references to other initiatives. This procedure resulted in a theoretical sample of 216 CSR initiatives from industrial and non-industrial sectors, agribusiness included as well (Figure 1).

For this article, we focused on the 59 initiatives in agribusiness, excluding CSR related initiatives that apply to all industries (e.g. the UN Global Compact, ISO 26000). To further narrow down on strategic CSR integration and sustainability in mainstream agriculture and food production, we first focused on initiatives that are led by the private-sector, or are characterized by a high privatesector involvement. Second, we selected initiatives that are applicable on a global or supranational scale. Third, we focused on agribusiness activities related to food and beverage production and processing, including commodities that are traditionally imported from developing countries. We excluded initiatives related to tobacco, cotton, cut flowers, and marine products (notably fish). Fourth, we excluded mandatory and quasi-mandatory food safety standards (e.g. HACCP systems), and organic regulations as well as the Fair Trade Generic Standards. Fifth, we did not consider initiatives from single companies (e.g. the Starbucks Coffee and Farmer Equity C.A.F.E. Practices). This selective process resulted in a sample frame of 14 initiatives (Table 1).

For addressing the next questions in our problem statement (i.e. extend, aim, scope, and members of these initiatives) we decided that the nature of the questions and the newness 


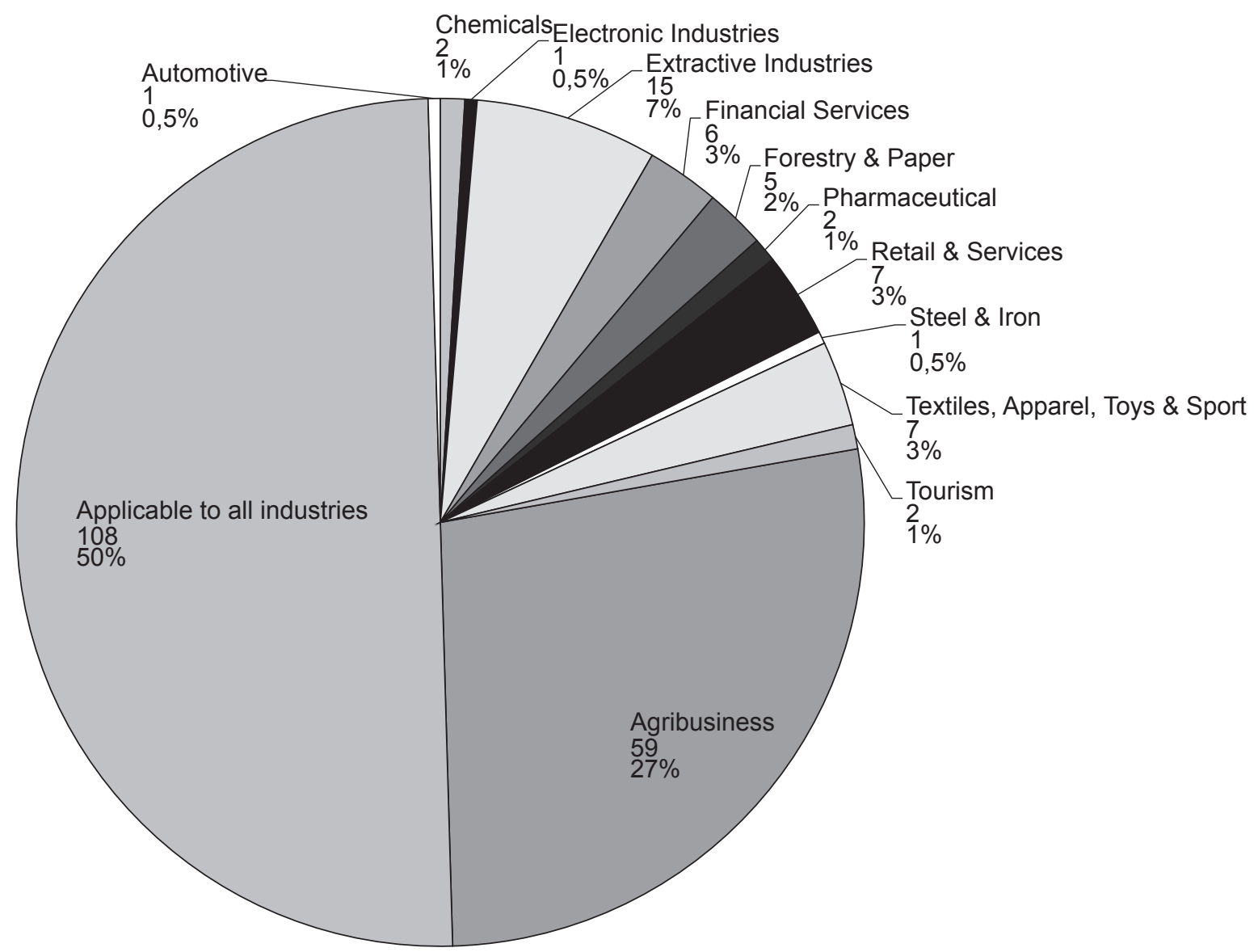

Figure 1. Corporate social responsibility initiatives by sectors, frequency and percentage $(n=216)$.

of the phenomena merits a single-case study approach in order to provide an in-depth understanding (Yin, 1994). From the sample frame in Table 2, we selected the SAI platform and its principles as a particularly interesting case for an institutional innovation in the form of a supraorganizational membership platform promoting sustainable agriculture on a global scale. Considering the diversity of food industry and the challenges competitors often face while working together in order to address sustainability initiatives, it is worthwhile to identify the leading good example that can serve as a baseline to further scrutiny. There is a strong agreement in scholarly literature that SAI platform stands out as the key example showing the superior performance over other initiatives (Haverkort et al., 2008; Millard, 2007; Smith, 2008). In line with Crespi and Marette (2005) we thus identify superior performance of one selected scheme for an in-depth single-case analysis. We acknowledge that case study outcomes cannot be generalized. However, the gained insights into related phenomena often assist theory building and hypothesis formulation, and are justified for particularly interesting cases (Yin, 1994). Furthermore, we compare and contrast this case study results with other initiatives and the literature in the discussion part of the paper, and encourage further multiple case studies.

For case data we retrieved online information from the SAI website in 2009, and in 2011, after a major website update in 2010. We further triangulated data from reports or documents published by other organisations. For analysis of the data and comparisons with the remaining initiatives we relied on Rasche's (2009) tripartite model of content, process, and context. Table 2 further outlines Rasche's (2009) exemplary aspects assisting contrast and comparisons of various standards. These are specificity and legitimacy of norms, implementability and accountability, geographic scope, and industry focus. The model is designed for accountability standards, however, in a slightly adapted form we found it useful for analysis of the SAI platform. 
Table 1. Selected private-sector driven CSR initiatives in agribusiness with global applicability.

\begin{tabular}{|c|c|c|c|}
\hline $\begin{array}{l}\text { Case } \\
\text { number }\end{array}$ & Standard/Guideline/Initiative & Focus & Mechanism \\
\hline 1 & Global Dairy Agenda for Action & Environmental & Policy framework \\
\hline 2 & Ethical Tea Partnership Standard & Socio-environmental & Accounting/auditing \\
\hline 3 & Sure Global Fair (SGF) Code of Conduct & Socio-environmental & Code of conduct \\
\hline 4 & $\begin{array}{l}\text { Round Table for Responsible Soy (RTRS) Principles and Criteria for } \\
\text { Responsible Soy }\end{array}$ & Triple bottom & Accounting/auditing \\
\hline 5 & Better Sugarcane Initiative (BSI) Standard & Triple bottom & Accounting/auditing \\
\hline 6 & $\begin{array}{l}\text { Roundtable on Sustainable Palm Oil (RSP0) Principles and Criteria } \\
\text { for Sustainable Palm Oil Production Including Indicators and } \\
\text { Guidance }\end{array}$ & Triple bottom & Accounting/auditing \\
\hline 7 & Utz Certified Coffee Code of Conduct & Triple bottom & Accounting/auditing \\
\hline 8 & $\begin{array}{l}\text { Common Code for the Coffee Community ( } 4 \mathrm{C}) \text { Code of Conduct and } \\
\text { Verification System }\end{array}$ & Triple bottom & Accounting/auditing \\
\hline 9 & Sustainable Agricultural Supply Chain Network & Triple bottom & Information/networking \\
\hline 10 & Sustainable Food Laboratory & Triple bottom & Information/networking \\
\hline 11 & GLOBAL GAP Good Agricultural Practice G.A.P. & Triple bottom & Policy framework \\
\hline 12 & Sustainable Agriculture Initiative (SAI) Platform Principles & Triple bottom & Policy framework \\
\hline 13 & World Cocoa Foundation Sustainability Principles and Goals & Triple bottom & Policy framework \\
\hline 14 & $\begin{array}{l}\text { Global Reporting Initiative (GRI) Reporting Guidelines - Food } \\
\text { Sector Supplement }\end{array}$ & Triple bottom & Reporting/monitoring \\
\hline
\end{tabular}

Table 2. A model to compare and analyse corporate social responsibility related initiatives (adapted from Rasche, 2009).

\begin{tabular}{|c|c|c|c|}
\hline & Content & Process & Context \\
\hline Guiding question & $\begin{array}{l}\text { What content-related rules does } \\
\text { the initiative propose? }\end{array}$ & $\begin{array}{l}\text { What implementation } \\
\text { processes does the initiative } \\
\text { propose? }\end{array}$ & $\begin{array}{l}\text { In which context does the } \\
\text { initiative operate? }\end{array}$ \\
\hline \multirow[t]{2}{*}{$\begin{array}{l}\text { Exemplary issues to compare } \\
\text { and analyse standards }\end{array}$} & $\begin{array}{l}\text { Specificity of Norms: Are the } \\
\text { rules proposed by the initiative } \\
\text { specific enough to foster } \\
\text { implementation? }\end{array}$ & $\begin{array}{l}\text { Implementability: Are the } \\
\text { required implementation } \\
\text { processes specifically laid out? }\end{array}$ & $\begin{array}{l}\text { Geographic scope: In which } \\
\text { countries/regions is the } \\
\text { initiative active? }\end{array}$ \\
\hline & $\begin{array}{l}\text { Legitimacy of Norms: Was the } \\
\text { initiative developed in a multi- } \\
\text { stakeholder way? }\end{array}$ & $\begin{array}{l}\text { Accountability: Does the } \\
\text { initiative require the creation } \\
\text { of accountability processes? }\end{array}$ & $\begin{array}{l}\text { Industry focus: On which } \\
\text { industry (or industries) does } \\
\text { the initiative focus? }\end{array}$ \\
\hline
\end{tabular}

We base our argumentation for relating the case to the three criteria and guiding questions defined by Rasche (2009) on a limited number of alternatives, and the suitability of the selected model. Although scholars have started to describe the different characteristics of global CSR initiatives and standards (e.g. Leipziger, 2003), academic typologies and models for simultaneously comparing and analysing them are only emerging (Kolk and van Tulder, 2002; 2005; Preuss, 2010; Rasche, 2009; Van Tulder et al., 2009). We select Rasche's model because it specifically addresses supra-organizational initiatives, and is related to how CSR can be managed and what methods are useful (Dobers, 2009). For our approach, the model is generic enough to cover the broad range of issues related to the sustainability 
debate and CSR. Instead of proposing specific criteria, it consists of questions and exemplary issues to guide analysis, introduce a common terminology (i.e. content, process, and context issues), and serve as a 'yardstick' for analysing the strengths and weaknesses of an initiative (Rasche, 2009). Therefore, the model supports our exploratory approach through its potential to uncover unanswered questions as well as unquestioned answers related to the different dimensions of analysis (e.g. how specific is the initiative, why is it developed, by whom, and what is their mandate). Furthermore, we use the structure of the model in the discussion section to compare and contrast our results with the literature and other initiatives.

\section{Results}

\section{Case overview: the sustainable agriculture initiative platform and its principles}

The SAI Platform was founded in 2002 by three global players in the food industry: Nestlé, Groupe Danone and Unilever. SAI defines sustainable agriculture as 'a productive, competitive and efficient way to produce agricultural raw materials, while at the same time protecting and improving the natural environment and social/economic conditions of local communities' (SAI, 2009a). Today SAI claims to be the '... only global food industry initiative for sustainable agriculture' (SAI, 2010b).

In 2009, SAI referred to the SAI Platform Principles as sustainable agricultural practices that embody the following principles: (1) Provide the base for ensured food safety; (2) Secure adequate food supplies to meet current and future food demand; (3) Protect and possibly improve the natural environment and resources; and (4) Support economically viable and responsible farming systems (SAI, 2009b). In 2010, however, SAI revised its principles. They still emphasize the 4 points and define sustainable agriculture as '... a productive, competitive and efficient way to produce safe agricultural products, while at the same time protecting and improving the natural environment and social/economic conditions of local communities' (SAI, 2010a), but now SAI offers a subset of more detailed 'Principles \& Practices' for arable and vegetable crops, coffee, dairy, and fruit.

\section{Sustainable agriculture initiative content: specificity}

The specificity of a standard is essential for successful implementation and for avoiding misinterpretation (Leipziger, 2003). Moreover, a high specificity of rules increases trustworthiness (Bruno and Karliner, 2000) and facilitates verification and auditing (DeRuisseau, 2002). The 2009 SAI Platform Principles were, however, far from being specific, and left plenty of room for interpretation. SAI itself acknowledged that sustainable agriculture is a long term goal and a continuous learning process, and that the platform should be seen as common framework that can provide answers to basic questions about sustainable agriculture (SAI, 2009d). The principles were meant to support the implementation of sustainable agricultural practices by evaluating and assessing practices against them, and thus explore their potential for contributions to sustainable agriculture. In doing so, the SAI platform claimed to have an inclusive approach and take any valuable (that is contributing to sustainable agriculture) initiative and concept into account, e.g. elements from both integrated and organic farming (SAI, 2009b).

Today, SAI has transformed its 2009 principles into a definition of sustainable agriculture, and has introduced more detailed 'Principles \& Practices' for 4 product groups. For example, the arable and vegetable crops document is organized in 4 chapters (sustainable farming systems, and economic, social, and environmental sustainability). Each chapter includes items (e.g. site selection and management), principles (e.g. consider previous land use), and recommended practices (e.g. risk assessment) (SAI, 2010d). Similar documents are available for coffee, dairy, and fruit (SAI, 2010a), and are in planning for sustainable water management (SAI, 2010f). Through the new subset, SAI has increased the specificity of its guidelines. However, they are still at the level of guiding principles, and not specific verification or auditing standards.

\section{Sustainable agriculture initiative content: legitimacy}

The SAI Platform is a private sector initiative that was developed against the backdrop of challenges food producers face in their supply chains. In 2003, Hans Jöhr, Nestlé's corporate head of Agriculture and President of the SAI Platform, highlighted the drivers of change for agribusiness: a growing population, limited resources, globalisation and changing consumer expectations, in particular towards transparency and traceability (Jöhr, 2003). Jöhr explains Nestlés commitment to the SAI platform with the need to develop sustainable agriculture as the food industry relies on agricultural productivity and the long term supply of raw materials, as well as consumer confidence in quality and safety. Today, SAI has gained further members and claims that the platform is open for active membership to all food industry companies willing to agree with the platform principles, and to support sustainable agriculture, 
i.e. through supporting the platform both financially and with knowledge and expertise.

In 2010, SAI tried to strengthen its legitimacy by collaborating with the Confederation of the Food and Drink Industries of the EU and the European Initiative for Sustainable Development in Agriculture (EISA). Both have become affiliate members next to the dairy technical solutions provider DeLaval, the Global Dairy Platform, and the Global Forum for Rural Advisory Services. Additionally, the SAI Platform has had cooperation and partnerships with the Sustainable Food Laboratory, Field to Market, the International Dairy Federation, GLOBAL GAP, the Roundtable on Sustainable Palm Oil, and the 4C Common Code for the Coffee Community Association (SAI, 2008 and SAI, 2007). The SAI Platform also contributes to the UN Global Compact. Hans Jöhr's participation in the UN private Sector Forum 'The Millennium Development Goals and Food Sustainability' in 2008 was connected to the UN publication 'Food Sustainability - a guide to private sector action', in which a section is dedicated to the SAI Platform (SAI, 2008).

Regarding active company members, legitimacy is affected by membership fluctuations. 25 active members include the three founders (Nestlé, Danone, Unilever), and Agrarfrost Germany, Agroterra, Aviko, Cayuga Marketing, CIO Parma, Coca Cola, FarmFrites, Fonterra, Friesland Campina, General Mills, Heineken, Illy, Kellog's, Kemin, Kraft Foods, Lamb Weston, McCain, McDonalds, Novus, Pepsico, Sarah Lee, Tchibo. While membership in total has grown, a number of companies also left the platform: Volcafe, the Neumann Kaffee Gruppe and Ecom left the SAI in 2008 (SAI, 2008). Danisco and Dole were mentioned as member companies in Jöhr (2003), but do not appear in later documents.

\section{Sustainable agriculture initiative process: implementability}

The SAI Platform wants to play an important role in the recognition and implementation of sustainable practices for mainstream agriculture (SAI, 2009b). Yet in practice, the platform faces constraints because of different practices in different value chains (e.g. in milk, fruit or coffee production) that lead to a diversity in approaches towards sustainable agriculture. Additionally, pilot project experiences showed that local schemes need to be promoted (CSR Europe, 2009). To ease this constraint, the SAI Platform established specific working groups, initially on cereals, coffee, dairy, fruit, potatoes, vegetables and water. The groups are led by members of the SAI Platform and are supposed to work on pilot projects (including cost-benefit studies), develop general as well as crop-specific frames to assess agricultural practices, and establish guidelines for sustainable agricultural practices (SAI, 2009c). The following two examples illustrate tasks of the working groups: first, the potatoes, vegetables and cereals working group merged in 2008. They jointly benchmarked their own principles and practices with the EISA framework for integrated farming, a process that resulted in the 'Principles \& Practices' for arable and vegetable crops (SAI, 2010d). The SAI Platform claims that the benchmarking process showed that environmentally there is a big equivalence, but the SAI Platform's view on social issues and farm economics is more elaborate. Moreover, the group worked on similarities and differences between organic and sustainable agriculture, the new EU pesticides regulations, and the shift from a crop specific to a farm or crop rotation approach (SAI, 2008). Secondly, next to the development of principles and practices for dairy production, the dairy working group is working on methods to calculate greenhouse gas emissions at the farm level (SAI, 2009f).

Next to the development of principles and practices, and tools for sustainable agriculture, implementability is addressed through testing the developed schemes in pilot projects. By 2009 there had been 64 member programmes and pilots (SAI, 2009e). One example in Vietnam is Kraft and Sara Lee's 'Improvement of the sustainability of Arabica coffee cultivation and processing in Huong Ho' Programme, which includes the implementation of coffee quality standards and the establishment of a monitoring system for environmental aspects of post-harvest processing. In addition, the documents and tools are benchmarked with guidelines and recommendations from other schemes (SAI, 2010g). In sum, SAI states that all documents are meant to be revised regularly, need to be complemented with specific guidelines and practical tools, and adapted to local socioeconomic and environmental conditions (SAI, 2010d).

Implementation in the member companies is facilitated through access points, knowledge sharing in the working groups, research and development, technology monitoring, conferences, and trainings. The implementation goals are practical support, innovations, and the development of human capital (SAI, 2010g).

\section{Sustainable agriculture initiative process: accountability}

There are no specific reporting procedures or performance targets. The SAI Platform Principles are also not associated with a certification system or a label, and SAI does not aim to set up a certification system at present (SAI, 2009b). Instead, the developed 'Principles \& Practices' are 
benchmarked with standards and guidelines established by 'key initiatives and schemes', for example the International Labour Organisation conventions (SAI, 2010c). The working groups also collaborate with other standards and guidelines in the specific value chain, e.g. the coffee working group collaborated with the Common Code for the Coffee Community. In addition, the SAI members represent a large part of the global market for food products and may ask their suppliers to participate in pilot projects or implement guidelines that are based on the principles developed by the platform or of one of the members (Dankers and Liu, 2003).

Platform accountability is further shaped by regulatory documents of the organisation. These include statutes, by-laws, a code of conduct, and since 2010 also an antitrust statement (SAI, 2010e). The statutes and by-laws mainly address the membership fees, termination of the membership and management issues, but they also state that active members have to agree to the principles and are expected to support sustainable agricultural practices within their field of business. The code of conduct reinforces the commitment to the principles and to working towards their implementation, as well as strict adherence to the anti-trust statement. Additionally, it encourages companies to report annually on progress. Finally, the code of conduct also states that breaches of the code, the statutes or the by-laws, may lead to the exclusion of member organisations. The section is, however, very careful about public action upon breaches. Members are supposed to resolve grievances directly with other members and report unresolved allegations to the executive committee prior to taking public action. In terms of the visibility to the end consumers, members may use the SAI membership in advertising campaigns and materials. However, they cannot infer SAI indorsement of their products.

\section{Sustainable agriculture initiative context: geographic scope}

The goal of the SAI platform is to support the implementation of sustainable agriculture practices worldwide. Thus, its principles are potentially applicable on a global level. In 2009, the database of Members' Programmes and Pilots (SAI, 2009e) showed that the principles serve as a yardstick for sustainable agriculture in particular regions or countries. On distinguishing between the geographic origin of participating companies and their suppliers, the participating companies are mostly European food industry companies, or European affiliates of international big players. The suppliers on the other hand are farms and agricultural cooperatives in developed and developing countries.
In 2008 SAI started to reach out towards the North American Market. They established collaborations with two US-based organisations, the Sustainable Food Laboratory and the Keystone Centre Field to Market. Additionally, sub-platforms emerged on the Philippines and in Australia. The Philippine Chapter of the SAI Platform is a legal entity under the Philippine Chamber of Food Manufacturers. The Australian Chapter comprises eleven of the leading agricultural, food and beverage processing and input supply corporations in Australia (SAI, 2008).

\section{Sustainable agriculture initiative context: industry focus}

The SAI Platform is designed for the food industry and targets sustainable agricultural practices in food production. Within the broad range of food value chains, the working group themes identify the production of arable crops, vegetables, coffee, dairy, fruit, and sustainable water usage in agriculture as the sub-sectors SAI focuses on. In addition, a new working group on beef production has been launched. It will collaborate with the WWF's Global Sustainable Beef Initiative and the Sustainable Livestock Production Initiative launched in the US. Core topics of the new working group will be greenhouse gas emissions and life cycle analysis (SAI, 2010h).

For market segments, SAI explicitly mentions that its target is mainstream agriculture and not niche markets. SAI argues that mainstream agriculture produces the components of the majority of food products worldwide, and that continuous improvement along the three pillars of sustainability should allow for a successful implementation by the majority of food chain stakeholders (SAI, 2010g).

\section{Discussion}

The SAI platform is a representative example for a CSR initiative of large multinational food companies. For several reasons they have to be involved in global CSR initiatives. First, agribusiness is a global business with complex food value chains. Therefore any larger CSR initiative needs global players to emphasize its meaningfulness. Corporations manage complex global food chains which are connected to or rooted in developing countries. These contexts are often characterized by deficits concerning social and working standards, weak governance standards, scarce resources, and threats to biodiversity. Second, corporations risk brand reputation, company image, and customer relationships in case of negative publicity due to unsustainable business practices. A proactive engagement in a global CSR platform can be an 'insurance' payment against unforeseeable public relation scandals. The emergence of large initiatives 
such as the SAI is also possible because global food and agribusiness companies possess the resources to act as CSR standard 'leaders', using their powerful position to promote the expansion of CSR guidelines downstream to 'smaller' partners in the supply chains (Ingenbleek and Frambach, 2010). On one hand the pure size of multinational companies and their position in multiple global food networks makes them vulnerable to public opinion and stakeholder pressure, on the other hand their size alone puts them into the 'chair of responsibility' to enforce global CSR standards.

From a marketing point of view it is interesting that global agribusiness players are collaborating instead of developing their own standards. There may be two reasons for this phenomenon. First, the collaborative development and communication of a global CSR standard is more cost efficient. Second, social or environmental scandals could harm the image of the whole food sector, not only damaging one specific player but discrediting all. Moreover, the emergence of players who pursue a clear responsibility strategy, such as organic and fair trade, has put competitive pressure on brands of large companies.

For further discussion of these points we follow the structure of Rasche (2009). We focus on discussing the case findings with other initiatives, and with the literature on CSR in general.

\section{Content: specificity}

The SAI platform has made progress in increasing the specificity of their guidelines. Starting with very broad principles, the platform now offers more detailed principles and practices for different value chains. However, the updated documents are still not specific enough for verification or auditing. This non-specificity is, however, not necessarily a weakness and should be put into perspective (Rasche, 2009). The SAI is a comprehensive policy framework encompassing information sharing, the development and benchmarking of guidelines and tools, and testing through pilot projects. It is currently not their aim to develop verification procedures. Instead, SAI focus on harmonisation with existing and recently developed auditing schemes, for example the $4 \mathrm{C}$ verification procedures. Furthermore, one needs to consider that SAI is a global initiative that needs to take varying regulatory and environmental conditions in production countries into account. So far SAI's approach is to provide best-practice examples that need to be revised, complemented, and adapted to local conditions.
Similar examples can be found among CSR initiatives that apply to specific sectors (e.g. the Equator Principles in the finance sector), or to all industries (e.g. the UN Global Compact). Due to the contingency nature of CSR (Salzmann et al., 2008), the majority of initiatives across sectors are similar policy frameworks that include a set of principles, and then vary in their comprehensiveness (e.g. networking platforms, membership organisations, embedded auditing standards for specific CSR related issues). In agribusiness, the GLOBAL GAP Good Agricultural Practices are becoming a comprehensive policy framework. Starting out as a European retail-driven initiative to ensure food safety, the GAP standards have gained a quasi-mandatory status, and the organisation itself has turned into a globally operating private sector body that claims to take social, environmental and stakeholder issues into account (GLOBALGAP, 2011a). Converging and conflicting issues between the SAI and the GAP framework offer an interesting perspective for further studies. In terms of specificity, what an organisation claims might not reflect the actual content. GLOBAL GAP and its antecessor EUREPGAP include social and environmental aspects only to a limited extend and in the form of 'minor musts', but supermarkets referred to EUREPGAP as part of their CSR commitment (Vander Stichele et al., 2006).

\section{Content: legitimacy}

The SAI was initiated as a measure to improve both the founding companies' CSR profiles, and their long term triple bottom lines. From a theoretical perspective, the initiative can be seen as a reaction to stakeholder pressure, but also as a business-case oriented answer to concerns about the future supply of agricultural raw materials. To judge legitimacy of the rules incorporated in a standard, Rasche (2009) considers moral legitimacy based on mutual communication between affected parties as an appropriate benchmark. For the SAI platform and principles, the business-case orientation and private-sector origin, however, can complicate the establishment of moral legitimacy. After all, concerns about an ultimate economic bottom line (Estes, 1996) remain. Thus, SAI has been focusing on obtaining external recognition from other actors in the food chain by attracting further food companies to join the platform, and involving stakeholders such as farmer groups, NGOs, policy makers, and authorities (BASD, 2002).

Today, the 25 listed members are all large food or beverage companies. However, the member list has seen some fluctuations over time. For legitimacy, this raises questions why they left the initiative. Especially Dole's involvement in the SAI Platform is particularly interesting, as the company is under public scrutiny for environmental pollution and 
unfair treatment of their workforce (e.g. EvB, 2008). From the corporate perspective, the question is also about internal legitimacy. Managers have to balance costs and benefits and are supposed to '...treat their decision regarding CSR as they treat all their long-term investment decisions' (Cruz and Wakolbinger, 2008). In some cases, the costs of participation might have outweighed the benefits. Alternatively, the literature also suggests that strategic integration of CSR seems to move away from the endorsement of existing international standards to the creation of company specific standards. In doing so, companies may signalise proactiveness, optimally contribute to the supply chain, and obtain project ownership (Oettingen, 2008a,b). Regarding the latter, SAI members might use the platform for marketing campaigns. However, they cannot infer SAI indorsement of their products. Further analysis can investigate if such arguments influenced the decision of the Neumann Kaffee Gruppe. The company left the platform in 2008, and has established its own sustainability project through collaborating with a number of stakeholders (NKG, 2011). Furthermore, strategic partnerships between civil society organisations and businesses gain momentum in the field of CSR and CSR standards (Eweje, 2007; Gonzalez-Perez and McDonough, 2005). Chiquita's cooperation with the Rainforest Alliance is a good example for this development (Chiquita Brands International, 2006; SAN, 2009).

The SAI itself shows that individual CEOs and companies have become more active in issuing guidance documents and establishing networks or membership associations. In comparison with other initiatives, these activities indicate a trend towards third generation CSR activities and instruments. For example, the Sure Global Fair Code of Conduct focuses on legal compliance and correct behaviour. It reflects first and second generation notions of what 'not to do', and focuses on adequate compensation and working conditions (Stohl et al., 2007). On the other hand, the more recent initiatives are eager to signalize pro-activeness, and derive their legitimacy from involving external stakeholders. The SAI increases its mandate as a provider of guidelines for sustainable agriculture through its affiliate members and collaborations within the working groups (e.g. with NGOs such as the Sustainable Food Laboratory or the WWF). Other private-sector driven initiatives, such as the roundtables for soy or palm oil, also explicitly emphasize their multi-stakeholder approach by claiming to take the interests of concerned parties into account. Furthermore, EUREPGAP has been criticised for lacking credibility from other stakeholders, such as NGOs and trade unions, and for being a potential constraint for developing countries and small farmers (Vander Stichele et al., 2006; FAO, 2007). After a re-branding to GLOBAL GAP in 2007, the organisation now claims to consider interests of involved parties through stakeholder consultation and smallholder involvement (GLOBALGAP, 2011b).

Yet 'who or what really counts' (Freeman, 1984) and how stakeholder engagement is facilitated is subject to further analysis. For our case, SAI's affiliate members and partners are organisations and initiatives that share the triple bottom line approach. Additionally, the collaborating NGOs can be categorised as 'business-friendly'. This leaves open questions for the legitimacy of the initiative among other organisations. Particularly interesting is how proactive behaviour can benefit sustainability transformation, but also to which extend processes can be taken control of, and power relationships can be influenced.

\section{Process: implementability}

Implementation of SAI's sustainable agriculture principles is facilitated through a value-chain specific approach. The working groups focus on single products or product groups, and issue more detailed guidelines. Member companies concentrate their involvement on the working group that is in their line of business, and collaborating partners and benchmarks are also value-chain specific. In addition, the implementation of sustainable agriculture is supposed to be driven by networking and knowledge sharing, the development of human capital and tools, and through pilot projects.

In comparison with others, the SAI platform is not the only initiative that embeds the implementation of its principles into a broader policy framework of a membership organisation, networking platforms, collaborations, and pilot projects. The new roundtable initiatives for soy or palm oil are organised similarly. Flexibility, stakeholder consultation, and feasibility are likely to be major drivers behind this approach. However, the creation of membership organisations that influence standard diffusion and adoption blurs the boundary between standardisation and a formal organisation, and becomes a globalising process in itself (Brunsson and Jacobsson, 2000). Questions that need to be addressed go back to the legitimacy of such strategic partnerships to create membership organizations and issue rules for stakeholders; and the responsibility that comes with it.

\section{Process: accountability}

CSR membership organisations have an interest to hold their members accountable, as negative feedback from stakeholders on the actions of individual members 
can discredit the whole initiative. For the SAI, cautious regulatory documents shape this internal accountability. Noteworthy points here are negative and costly effects that might arise out of image damages and of lawsuits accusing the company of non-compliance with the principles. In this context, Rasche (2009) upon analysis of the Global Compact already highlighted that the under-representation of North American companies among Global Compact endorsers can be partly attributed to the fact that Northern American societies, in particular the US, are more litigious than Europe or Latin America. With the SAI Platform starting to reach out towards the North American market, this difference may affect membership of US companies, and shape the regulatory documents of the organisation. The recently added anti-trust statement seems to be an example for this process.

For external accountability, the SAI principles and practices are not designed for verification and certification through (third-party) audits, unlike most of the standards and guidelines in agricultural production, and CSR related auditing standards such as SA8000. The SAI approach is to refer to auditing schemes and collaborate with certifying organisations. In doing so, the final consumer in the supermarket will not be directly aware of the SAI. Although members might use SAI endorsement for marketing and PR, the platform is in the first place a business-to-business (B2B) and strategic partnership initiative. The platform manages its broad focus by steering around direct accountability through providing principles and practices that need to be complemented with specific guidelines.

\section{Context: geographic scope}

SAI claims to be a global initiative. In practice, however, the application of standards that tend to be globally valid is in fact often restricted to particular regions or countries (Rasche, 2009). This also holds for the SAI Platform and its principles. The participating companies are mostly European food industry companies, or European affiliates of international big players. The suppliers on the other hand are farms and agricultural cooperatives in developed and developing countries, in which agricultural practices and regulatory frameworks may vary substantially.

The trend to go global is reflected in other initiatives as well. Prominent examples are the Global GAP (former EUREPGAP), or the Utz certifications that expanded from a smaller producer-trader collaboration to a major commodity certifier for the new responsible production schemes for coffee, cocoa, and tea. Utz also manages traceability for certified oil of the Round Table for Responsible Palm Oil
(Utz, 2011). This trend to 'go global' is largely driven by the third generation of CSR. Specifically in agribusiness increased stakeholder pressure and complex supply chains require global partnerships.

\section{Context: industry focus}

Overall, the industry focus of the SAI platform is clear. However, we use this chapter to discuss market segmentation within the food sector, as well as sub-sectors and addressed stages of the value chain.

In terms of market segmentation, the rise of CSR in agribusiness triggered the introduction of 'mainstream' initiatives for responsible production and ethical trade. The SAI with its focus on mainstream agricultural production and its claim to be the '... only global food industry initiative for sustainable agriculture' (SAI, 2010b) is a striking example for this development. In general, however, mainstream initiatives have lower or less stringent requirements regarding environmental and/or social issues than organic and fair trade standards. Additionally, they are less ethical value-oriented and often integrate the economic dimension to emphasize the triple bottom line and costefficiency, such as in the case of SAI. This trend reflects conventionalization of sustainability and raises a number of questions for the organic and fair trade market. SAI for example explicitly mentions that its target is mainstream agriculture and not niche markets. While it is essential to move sustainability into the mainstream, there is concern that 'watered down' standards for the mass market can be harmful and undermine trust in other labels (GTZ, 2006). Similarly, Hockerts and Wüstenhagen (2010) point out that mainstream adoption 'contributes positively to the sustainability transformation of an industry', but the 'price of gaining more breadth may be to lose depth in terms of sustainability quality'. For an example, Hockerts and Wüstenhagen mention that the Fairtrade Labelling Organisation 'has begun to relax some of its standards in response to the pressure from competing schemes such as the Rainforest Alliance label'. On the other hand, in a 'battle between good and better [...] sustainable development is best served by the synergy that results under 'co-opetition': when the two types of rival organisations coexist' (Ingenbleek and Meulenberg, 2006). Likewise, Hockerts and Wüstenhagen (2010) point out that the competition might lead to the creation of new high-end market niches. Much of this remains to be seen. Products that are dominantly produced in developing countries, notably coffee and cocoa, traditionally have been on the agenda of organic production and fair trade. Now that the first products from the mainstream initiatives have entered 
the market, consumer responses and market reaction of the traditional commodity niche markets are interesting topics for further studies. In this context, an Austrian study on CSR and organic farming suggests that the sector could react to this 'conventionalization' of sustainability with 'higher ethical standards in organic farming and more effective communication of ethical values' (Goessinger and Freyer, 2008).

In terms of product segments, there is evidence for a product-based approach for CSR in agribusiness. The SAI case highlights that CSR in agricultural production requires a value-chain approach. This is in line with a number of value-chain specific initiatives that have been developed over the past 5 to 10 years, and target mainstream production. From our sample frame in Table 2, 8 out of the 14 selected CSR initiatives are focusing on one specific agricultural commodity (case 1 to 8 ). So far initiatives tended to focus on horticulture, floriculture and arable crops, and less on livestock. The dairy industry has started to react to concerns about carbon emissions, and very recently meat production has become a global CSR issue. The SAI platform has a new working group on beef, and has established links with new NGO initiatives such as the Global Sustainable Beef Initiative of the WWF. Further studies have a unique opportunity to monitor and evaluate the role of the SAI in the development of institutional innovations for sustainable mainstream production of products that are increasingly under public scrutiny. Theories on stakeholder salience (Mitchell et al., 1997) may be particularly useful for such investigations.

In terms of CSR along different stages of the value chain, SAI so far focuses on production at the farm level. CSR issues in the downstream supply chain, e.g. how food is processed, marketed, transported, and sold, are by definition not part of the initiative. However, internal CSR is usually addressed by corporate-specific CSR programmes and strategies. Moreover, the majority of corporations are involved in programmes from international organisations or industry lobbies, and report their CSR activities according to the Global Reporting Initiative, the leader among voluntary sustainability reporting systems (Brown et al., 2009). Similar to studies on CSR in general (Preuss, 2010), further studies may focus on how agribusiness companies integrate CSR initiatives at different levels of the organisation and the supply chain.

\section{Conclusions}

Over the past decade agribusiness corporations have become more pro-active in addressing sustainability concerns, leading to the introduction of several mainstream initiatives that start to compete with the traditional niche markets. New initiatives such as the SAI platform also show a shift from first and second to third generation CSR activities.

Our analysis is so far only exploratory, and is limited by the use of a single case and secondary data. However, we analyse a particularly interesting case of an institutional innovation that may hold substantial potential for the sustainability transformation of the sector. The SAI platform shows that global players in the food industry have started to operationalize their CSR engagement through supraorganisational partnership designed to tackle global sustainability issues of agricultural production. The platform itself is a networking and membership organisation whose principles and guidelines should help members to evaluate and adapt their sourcing practices. It mirrors a strategic response to the pressures and challenges food corporations face in the upstream supply chain, notably the assurance of sustainable production yields in the future. The SAI's major strength is its potential to move sustainability to mainstream production, embedded in the resources and collaborative efforts of the global players. However, SAI ultimately represents a triple bottom line approach that is largely driven by threats to future economic viability, and needs to gain legitimacy through increasing its members and involving external stakeholders.

For managing innovation processes for sustainability and their institutional context, we highlight the need for a systematic analysis of CSR initiatives to better understand underlying motives and driving factors behind an initiative. We emphasize that any evaluation of a private-sector led CSR initiative will have to take strategic objectives into account. This will allow for more meaningful statements about the potential strengths and weaknesses of a CSR initiative for sustainability transformation of the food and agriculture sector. We strongly encourage further studies that employ a systematic comparison of the SAI with other CSR initiatives, e.g. those identified in our sample frame. Such an approach could focus on different roles individual initiatives might play in an overall institutional framework for sustainability transformation, as well as how the potential of each initiative can be enhanced when combined with others.

\section{References}

Agribusiness Action Initiative (AAI), 2011. About AAI. Available at: http://www.agribusinessaction.org/index.php?option=com_con tent\&view=article\&id=7\&Itemid=9\&lang=en.

Aiking, H. and J. De Boer, 2004. Food sustainability: Diverging interpretations. British Food Journal, 106(5): 359-365. 
Aßländer, M.S. and K. Senge, 2009. Einleitung: Zur Bedeutung einer Corporate Social Responsibility für den Einzelhandel. In: M.S. Aßländer (ed.) Corporate Social Responsibility im Einzelhandel. Metropolis-Verlag, Marburg, Germany, pp. 7-24.

Bhattacharya, C.B., D. Korschun and S. Sen, 2009. Strengthening stakeholder-company relationships through mutually beneficial corporate social responsibility initiatives. Journal of Business Ethics, 85(2): 257-272.

Boehlje, M., 1993. Industry note environmental regulation and corporate policy. Agribusiness 9(5): 495-508.

Boller, E.F., J. Avilla, E. Jörg, C. Malavolta, F.G. Wijnands and P. Esbjerg, 2004. Guidelines for integrated production, principles and technical guidelines, 3rd Edition, IOBC WPRS Bulletin, $27(2)$.

Bowie, N.E. and P.H. Werhane, 2005. Management ethics. Blackwell Publishing, Malden, MA, USA.

Brown, H.S., M. de Jong and T. Lessidrenska, 2009. The rise of the global reporting initiative: a case of institutional entrepreneurship. Environmental Politics, 18(2): 182-200.

Bruno, K. and J. Karliner, 2000. Tangled up in blue: corporate partnerships at the United Nations. Transnational Resource and Action Center, San Francisco, CA, USA.

Brunsson, N. and B. Jacobsson, 2000. The contemporary expansion of standardization. In: Brunsson, N. and B. Jacobsson (eds.), A world of standards. Oxford University Press, New York, NY, USA, pp. 1-17.

Bullis, C. and F. Ie, 2007. Corporate environmentalism. In: May, S., M. Cheney and J. Roper (eds.), The debate over corporate social responsibility. Oxford University Press, New York, NY, USA, pp. 321-335.

Business Action for Sustainable Development (BASD), 2002. Sustainable Agriculture Initiative (SAI). The World Business Council for Sustainable Development and the International Chamber of Commerce. Available at: http://basd.free.fr/ initiatives/viewproject.php.151.html.

Carroll, A.B. and A.K. Buchholtz, 2002. Business and society: ethics and stakeholder management. 5th Edition, South-Western College Publishing, Cincinnati, OH, USA.

Chiquita Brands International, 2006. 2006 Annual Report. Available at: http://www.chiquitabrands.com/content/corpres/AR\%20 reports/2006AR-CRsection.pdf.

Crespi, J.M. and S. Marette, 2005. Eco-labelling economics: is public involvement necessary? In: Krarup, S. and C. S. Russell (eds.), Environment, information and consumer behavior. Edward Elgar Publishing, Cheltenham, UK, pp. 93-110.

Cruz, J.M. and T. Wakolbinger, 2008. Multiperiod effects of corporate social responsibility on supply chain networks, transaction costs, emissions, and risk. International Journal of Production Economics, 116(1): 61-74.
CSR Europe, 2009. Sustainable Agriculture Initiative (SAI) Platform. The European Business Network for CSR. Available at: http://www.csreurope.org/solutions.php?action=show_ solution\&solution_id=393.

Dahlsrud, A., 2006. How corporate social responsibility is defined: an analysis of 37 definitions. Corporate Social Responsibility and Environmental Management, 15(1): 1-13.

Dankers, C. and P. Liu, 2003. Environmental and social standards, certification and labelling for cash crops. Raw Materials, Tropical and Horticultural Products Service Commodities and Trade Division, Food and Agricultural Organisation of the United Nations (FAO), Rome, Italy.

DeRuisseau, D., 2002. Social auditing: an auditor's perspective. In: Scherer, A.G., K.H. Blickle, D. Dietzfelbinger, and G. Hütter (eds.), Globalisierung und sozialstandards. Hampp, Mering, Germany, pp. 223-234.

Dobers, P., 2009. Corporate social responsibility: management and methods. Corporate Social Responsibility and Environmental Management 16(4):185-191.

Dunphy, D., A. Griffiths and S. Benn, 2003. Organizational change for corporate sustainability. Routledge, London, UK.

Elkington, J. 1998. Cannibals with forks: the triple bottom line of 21st century business. Capstone Publishing, Oxford, UK.

Erklärung von Bern (EvB), 2008. Public eye awards shortlist 2008. The Bern Declaration. Available at: http://www.evb.ch/cm_data/ Dole_3.pdf.

Estes, R. 1996. Tyranny of the bottom line: why corporations make good people do bad things. Berrett-Koehler, San Francisco, CA, USA.

Eweje, G., 2007. Strategic partnerships between MNEs and civil society: the Post-WSSD perspectives. Sustainable Development, 15(1): 15-27.

Fliess, B., H.-J. Lee, O.L. Dubreuil and O. Agatiello, 2007. CSR and trade: informing consumers about social and environmental conditions of globalised production: part I. OECD Trade Policy Working Papers, No. 47, OECD Publishing. DOI $10.1787 / 246322000033$.

Food and Agriculture Organisation of the United Nations (FAO), 2007. Private standards in the United States and European Union markets for fruit and vegetables: implications for developing countries. FAO, Rome, Italy.

Freeman, R.E., 1984. Strategic Management: a stakeholder approach. Pitman, Boston, MA, USA.

Gesellschaft für Technische Zusammenarbeit (GTZ), 2006. Shaping globalisation: impacts of voluntary standards. Synthesis document of the International Conference on 'Shaping Globalisation - Impacts of Voluntary Standards' in Berlin, 24-25, October 2006. Available at: http://www.gtz.de/de/dokumente/ gtz2008-en-conference-documentation.pdf.

Global Good Agricultural Practice (GLOBALGAP) 2011a. Tour 2011 - Global GAP. Available at: http://www.tour2011.org/cms/ front_content.php?idcat=72\&lang=1. 
Global Good Agricultural Practice (GLOBALGAP) 2011b. Smallholder Involvement. Available at: http://www.globalgap. org/cms/front_content.php?idcat=70.

Goessinger, K. and B. Freyer, 2008. Corporate social responsibility and organic farming - experiences in Austria. In: Neuhoff, D., Halberg, N., Alföldi, T, Lockeretz, W., Thommen, A., Rasmussen, I.A., Hermansen, J., Vaarst, M., Lueck, L., Carporali, F., Jensen, H.H., Migliorini, P. and Willer, H. (eds.), Cultivating the future based on science. Proceedings of the Second Scientific Conference of the International Society of Organic Agriculture Research (ISOFAR), Vol. II, 18-20 June 2008 in Modena, Italy. FiBL, Frick, Switzerland, pp. 416-419.

Gonzalez-Perez, M.A. and T. McDonough, 2005. Bananas ethical quality: multi-stakeholders, corporate social responsibility and corporate governance. Center for Innovation and Structural Change (CISC) Working Paper No. 21, National University of Ireland, Galway, Ireland.

Haas, R., M. Canavari, S. Pöchtrager, R. Centonze and G. Nigro, 2010. Organic food in the European Union: a marketing analysis. In: Haas, R., M. Canavari, B. Slee, T. Chen and A. Bundit (eds.), Looking east looking west: organic and quality food marketing in Asia and Europe. Wageningen Academic Publishers, Wageningen, the Netherlands, pp. 21-46.

Haverkort, A.J., D.M. Jansen, F.J. De Ruijter and A. Verhagen, 2008. From food safety guidelines to quantified sustainability indicators: a transition to good practice schemes in food production in Europe. Outlook on Agriculture 37(1): 37-45.

Hockerts, K. and R. Wüstenhagen, 2010. Greening Goliaths versus emerging Davids - theorizing about the role of incumbents and new entrants in sustainable entrepreneurship. Journal of Business Venturing, 25(5): 481-492.

Ingenbleek, P.T.M. and M.T.G. Meulenberg, 2006. The battle between 'good' and 'better': a strategic marketing perspective on codes of conduct for sustainable agriculture. Agribusiness, 22(4): 451-473.

Ingenbleek, P.T.M. and R.T. Frambach, 2010. Marketing strategies for sustainable development. In: Trienekens, J., J. Top, J. van der Vorst and A. Beulens (eds.), Towards effective food chains. Models and applications. Wageningen Academic Publishers, Wageningen, the Netherlands, pp. 25-46.

Jöhr, H., 2003. Sustainable agriculture initiative. 'Beyond carbon - emerging markets for ecosystem services' Presentation for the Swiss Reinsurance Company, Rüschlikon, Switzerland. Published by the Forest Trends Association. Available at: http://www. foresttrends.org/ foresttr/documents/files/doc_729.pdf.

Kolk, A. and R. van Tulder, 2002. Child labor and multinational conduct: a comparison of international business and stakeholder codes. Journal of Business Ethics, 36(3): 291-301.

Kolk, A. and R. van Tulder, 2005. Setting new global rules? TNCs and codes of conduct. Transnational Corporations, 14(3): 1-17.
Konrad, A., A. Martinuzzi and R. Steurer, 2008. When business associations and a federal ministry jointly consult civil society: a CSR policy case study on the development of the CSR Austria guiding vision. Corporate Social Responsibility and Environmental Management, 15(1): 270-280.

Leipziger, D., 2003. The corporate responsibility code book. Greenleaf, Sheffield, UK.

McEwan, C. and D. Bek, 2009. The political economy of alternative trade: Social and environmental certification in the South African wine industry. Journal of Rural Studies, 25(3): 255-266.

Millard, E., 2007. Restructuring the supply chain. In: Scherr, S.J. and J.A. McNeely (eds.), Farming with nature: the science and practice of ecoagriculture. Island Press, Washington DC, USA, pp. 358-377.

Mitchell, R.K., B.R. Agle and D.J. Wood, 1997. Toward a theory of stakeholder identification and salience: defining the principle of who and what really counts. The Academy of Management Review, 22(4): 853-886.

Neumann Kaffee Gruppe (NKG), 2011. Tropical farm management - objectives. Available at: http://www.nkgtropical.cm/objectives.

Oettingen, M. 2008b. Coop NKL \& ethical coffee trading: good for farmers and for retailers. In: ICEP and CODESPA (eds.), Business and poverty: innovative strategies for global CSR. The Global CSR casebook 2008 edition, Austria, pp. 205-216.

Oettingen, M., 2008a. Business case carrefour: how to contribute to inclusive supply chains. In: ICEP and CODESPA (eds.), Business and poverty: innovative strategies for global CSR. The Global CSR casebook 2008 edition, Austria, pp. 189-203.

Ongkrutraksa, W.Y., 2007. Green marketing and advertising. In: May, S., M. Cheney and J. Roper (eds.), The debate over corporate social responsibility. Oxford University Press, New York, NY, USA, pp. 365-378.

Phillips, R. and R.E. Freeman, 2003. Stakeholder theory and organizational ethics. Berrett-Koehler Publishers, San Francisco, CA, USA.

Preuss, L., 2010. Codes of conduct in organisational context: from cascade to lattice-work of codes. Journal of Business Ethics, 94(4): 471-487.

Rasche, A., 2009. Toward a model to compare and analyze accountability standards - the case of the UN global compact. Corporate Social Responsibility and Environmental Management, 16(4): 192-205.

Salzmann, O., U. Steger and A. Ionescu-Somers, 2008. Determinants of corporate sustainability management: an empirical contingency approach. Zeitschrift für Betriebswirtschaft, 3(1): $1-22$.

Senge, K., 2006. Wie tragfähig ist CSR? Das Beispiel Wal Mart. Forum Wirtschaftsethik, 14(3): 19-29.

Sikor, T., 2008. Public and private in natural resource governance. A false dichotomy? Earthscan Publishing, Oxford, UK. 
Smith, B.G., 2008. Developing sustainable food supply chains. Philosophical Transactions of the Royal Society Biological Sciences 363(1492): 849-861.

Smith, G. and D. Feldman, 2004. Implementation mechanisms for codes of conduct. CSR Practice, Foreign Investment Advisory Service, Investment Climate Department. World Bank and International Finance Corporation, Washington DC, USA.

Steurer, R. and G. Berger, 2007. Policies on CSR in Europe: an overview of topics and instruments. In: Martinuzzi, A. and M. Tiroch (eds), Umweltwirtschaft: International, Interdisziplinär und Innovativ. Research Institute for Managing Sustainability, Vienna University of Economics, Austria, pp. 149-151.

Stohl, M., C. Stohl and N.C Townsley, 2007. A new generation of global corporate social responsibility. In: May, S., M. Cheney and J. Roper (eds.), The debate over corporate social responsibility. Oxford University Press, New York, NY, USA, pp. 30-44.

Studer, C., F., Haeni, H., Porsche, A., Staempfli and C. Thalmann, 2009. RISE - response-inducing sustainability evaluation: Model Synopsis. Swiss College of Agriculture, Zollikofen, Switzerland.

Sustainable Agriculture Initiative (SAI), 2007. Annual report 2007. Available at: http://www.saiplatform.org/site_files/uploads/ Annual\%20Report\%202007\%202.0.pdf.

Sustainable Agriculture Initiative (SAI), 2008. Annual report 2008. Available at: http://www.saiplatform.org/site_files/uploads/ Annual\%20Report\%202008.pdf.

Sustainable Agriculture Initiative (SAI), 2009a. What is sustainable agriculture. Available at: http://www.saiplatform.org/about_ sustainable_agriculture/our_vision/what_is_sustainable agriculture.html.

Sustainable Agriculture Initiative (SAI), 2009b. Our approach. Available at: http://www.saiplatform.org/about_sustainable agriculture/our_vision/our_approach.html.

Sustainable Agriculture Initiative (SAI), 2009c. Working groups. Sustainable Agriculture Initiative. Available at: http://www. saiplatform.org/about_us/working_groups.html.

Sustainable Agriculture Initiative (SAI), 2009d. What we do. Sustainable Agriculture Initiative. Available at: http://www. saiplatform.org/about_us/what_we_do.html.

Sustainable Agriculture Initiative (SAI), 2009e. Member's programmes and pilots. Sustainable Agriculture Initiative. Available at: http://www.saiplatform.org/about_us/what_we_do/ members_programmes.html.

Sustainable Agriculture Initiative (SAI), 2009f. Discussion paper: calculating GHG emissions in the dairy sector. Sustainable Agriculture Initiative. Available at: http://www.saiplatform.org/ uploads/Library/DiscussionpaperforcalculatingGHGemissionsinthedairysector-05-06-09.pdf.

Sustainable Agriculture Initiative (SAI), 2010a. Sustainable agriculture - definition. Available at: http://www.saiplatform. org/sustainable-agriculture/definition.

Sustainable Agriculture Initiative (SAI), 2010b. Who we are. Available at: http://www.saiplatform.org/about-us/who-we-are-2.
Sustainable Agriculture Initiative (SAI), 2010c. SAI Platform in action. Available at: http://www.saiplatform.org/activities/saiin-actions.

Sustainable Agriculture Initiative (SAI), 2010d. Principles and practices for the sustainable production of arable and vegetable crops. Available at: http://www.saiplatform.org/uploads/Library/ PPsArableVegetableCrops2009-2.pdf.

Sustainable Agriculture Initiative (SAI), 2010e. SAI regulatory documents. Available at: http://www.saiplatform.org/about-us/ governance-3/regulatory-documents/statutes.

Sustainable Agriculture Initiative (SAI), 2010f. Water \& agriculture. Available at: http://www.saiplatform.org/activities/workinggroups/water-agriculture.

Sustainable Agriculture Initiative (SAI), 2010g. What we do. Available at: http://www.saiplatform.org/about-us/what-we-do. Sustainable Agriculture Initiative (SAI), 2010h. Beef. Available at: http://www.saiplatform.org/activities/working-groups/beef.

Sustainable Agriculture Network (SAN), 2009. Sustainable agriculture standard. Available at: http://www.rainforest-alliance. org/agriculture/documents/sust_ag_standard.pdf.

Teuscher, P., B. Grüninger and N. Ferdinand, 2006. Risk management in sustainable supply chain management (SSCM): lessons learnt from the case of GMO-free soybeans. Corporate Social Responsibility and Environmental Management 13(1): 1-10.

Trienekens, J. and P. Zuurbier, 2008. Quality and safety standards in the food industry, developments and challenges. International Journal of Production Economics, 113(1): 107-122.

Utz, 2011. Utz certified good inside. Available at: http://www. utzcertified.org/.

Van Tulder, R., J. van Wijk and A. Kolk, 2009. From chain liability to chain responsibility: MNE liability to chain responsibility: MNE Approaches to implement safety and health codes in international supply chains. Journal of Business Ethics 85(2): 399-412.

Vander Stichele, M., S. van der Wal and J. Oldenziel, 2006. Who reaps the fruit? Critical issues in the fresh fruit \& vegetable chain (update). SOMO Centre for Research on Multinational Corporations, Amsterdam, the Netherlands.

Vogel, D., 2010. The private regulation of global corporate conduct: achievement and limitations. Business \& Society, 49(1): 68-87.

White, A.L., 2005. Fade, integrate or transform? The future of CSR. Business for Social Responsibility and Allan White, Tellus Institute, San Francisco, CA, USA.

Yin, R.K., 1994. Case study research: Design and Methods. 2nd Edition, Sage, London, UK.

Young, G., 2003. Fair trade's influential past and the challenges of its future. King Baudouin Foundation, Brussels, Belgium.

Zorn, T.E. and E. Collins, 2007. Is sustainability sustainable? Corporate social responsibility, sustainable business and management fashion. In: May, S., M. Cheney and J. Roper (eds.), The debate over corporate social responsibility. Oxford University Press, New York, NY, USA, pp. 405-416. 
